\title{
THE ROLE OF ENGLISH EDUCATION AS THE SOLUTION OF THE SOCIAL WELFARE PROBLEM IN INDONESIA
}

\author{
Anisah Setyaningrum \\ STAIN Kudus, Central Java, Indonesia \\ anisahsetya17@gmail.com
}

\begin{abstract}
The problem of social welfare becomes the theme which has been often to be discussed. This paper aims to describe the role of English Education as the solution of society's welfare problem in Indonesia. English as an international language has become a compulsory subject in every level of education since last two decades. There are many advantages that can be gained by mastering English well, one of them is able to improve someone's welfare level. One of the roles of English in increasing the Indonesian society's welfare is English can be a potential provision in conducting entrepreneurship. In the other hand, it will increase their income. Besides, by having a good English mastery can facilitate them in gaining a better job.
\end{abstract}

Keywords: the role of English, social welfare problem 


\section{A. Introduction}

Indonesia is a big country which has a tremendous population. At least 250 millions people live in this whole archipelago area. It has a legend title which is very popular. As was sung by Koes Plus, "people said that our land is a paradise land, wooden stick and stone becomes plants." There are others similar compliment, one of them is 'the emerald equator', and so on. It shows how wealth this country is. However, in vise versa, all of us know well about the real condition of the society's welfare in Indonesia. There are so many jobless people and job vacancy that can not pervade all of workers. It is very awful.

There are many assumptions that Indonesian society mentality is agrarian, worker, and only can be labour not a leader or activator. That assumption can be right. The fact is that work community level is dominated by the young generation who look for job vacancy, while the job opportunity which provided by the government is not match with the flow of school and university graduates.

As mentioned above that one of the big problems in Indonesia year by year is the high of jobless number. Ironically, people who are in productive phase take a big number of the whole jobless amount. In the other side, the people who are working must think hardly to determine the priority of their needs because of the lack of salary and income. Shortly, life prosperity still becomes a beautiful deram for the majority of Indonesian society. The competition becomes harder and strict, both for now and the next future.

Idi (2013: 60) said that between education and society development can not be separated each other. The advancement of a society and a nation is very determined by the education sector development in preparing the human resources which is appropriate with the period development.

The human resources of Indonesia in the future can not be separated from the national education function. In the Article 3 of the Republic Indonesia Constitution No. 20 Year 
2003 about National Education Sistem was mentioned that:

"Pendidikan nasional berfungsi mengembangkan kemampuan dan membentuk watak serta peradaban bangsa yang bermartabat dalam rangka mencerdaskan kehidupan bangsa, bertujuan untuk berkembangnya potensi peserta didik agar menjadi manusia yang beriman dan bertakwa kepada Tuhan Yang Maha Esa, berakhlak mulia, berilmu, cakap, kreatif, mandiri, dan menjadi warga Negara yang demokratis serta bertanggung jawab."

Based on the explanation above can be known that education has a big role in preparing the society to take part in developing the ability and character of a nation to compete in the globalization era.

One of the ability that can support the people in facing the globalization era is the ability of English mastery. In this paper, the author tries to describe the role of English education in the effort of solving the problem of society's prosperity in Indonesia.

\section{B. Discussion}

\section{English Education in Indonesia}

Every country has a means of communication that can fluent a relation between persons. This means of communication is called language. English is a very important language in this world. It is the international language that has been used by most of countries in this world. Huda (2000: 68) mentions five factors that have made English an international language:

a. Its internal linguistic features.

b. The large number of English speakers.

c. The wide geographical spread of where it is used.

d. Its importance in fields such as politics, international diplomacy, economics and business, science and technology, and culture. 
e. The use of English by countries which currently dominate world affairs economically, politically and culturally.

The English speakers are spread out in the whole world, as the first language, second language, or foreign language. In Indonesia, the position of English is as a foreign language. Lauder (2008: 12) mentioned that the current status of English as an international or global language is underpinned by its wide use in a range of fields such as politics, diplomacy, international trade and industry, commerce, science and technology, education, the media, information technology, and popular culture.

The history of the English development is actually begun since centuries ago, it is one of the oldest language and has very large area in its spread in the world. Until now, English has been become an international language. A language that is used as a means of communication in international is different from the national language used in that country only. There are several reasons why the English become the international language. One of them is because English is the oldest language in this world. It comes from the plains of Britain which is around the 8th century. Besides, English also has a very fast vocabulary development. More clearly the fact also mentioned that the nation of United Kingdom was the country which most frequently colonized the world, therefore the English language is very familiar and more widely used in various countries, especially of the English possessions there.

Meanwhile, the development of English in Indonesia has been begun for centuries when the ancestors of the Indonesian speakers are associated with various Nations in the world. Sanskrit was recorded earlier was brought in to Indonesia since the early date of the ad. This language is used as the language of literature and intermediaries in the spread of Hinduism and Buddhism. 
The development of foreign language (English) gives a positive impact for the Indonesian generation. The more people who are able to communicate in English will make the transfer of knowledge faster. English is the most important foreign language which is learned in Indonesia. Commonly, in Indonesia, English has been taught as a foreign language. The term of foreign language in language teaching sector is different with the second language. Foreign language is a language which is not used as the means of communication in a certain country where the language is taught. Meanwhile, second language is not the main language, but becomes one of the languages which are used in common in a certain country.

Meantime, foreign language is usually taught as one of subjects in a school with purpose to teach the basic communication to students and mastering four language skills (listening, reading, writing, and speaking) in its language with certain limitation. In Indonesia, the policy of English teaching as foreign language is changed in accordance with the time and policy changing which is influenced by the economic and political will.

Additionally, in the globalization era, everyone is demanded to prepare a qualified human resources especially in science and technology area. In according to master the technology well, it needs a sufficient knowledge so it can be utilized well in facing the demand of global world which is full of competition. Thereupon, the role of English is very important both in mastering the technology and interact with it directly. As the means of global communication, English must be mastered actively both spoken and written. As the world language, English is not only as the means of global communication, but also an academic need.

Based on the explanation above, it can be known that English is very important today. However, there are 
still many people who find difficulties in digging potential in the field of English. As we know that language is a tool to communicate, so the best way to learn English is by making it as a habit. By mastering the English actively, people will feel as if there are no more borders of the country, and with pride of course we can chant a single melodic lines and the world will be as one.

There are some benefits that can be drawn from the English language education. By having a good mastery in English, it is able to improve language acquisition. The more and more people who are able to communicate in English will make the science transfer process faster anyway. It also has a benefit in a variety of activities in the international level, relations, business, and school. Besides, it is also very good for physical condition and mind work ability.

English mastery really has a positive impact. As mentioned before, that the more people who are able to communicate in English, it will make the science transfer process faster, because many books have been written in English. The mastery of English also has a positive impact in all social activities, by mastering English, someone can gain a lot of friends and even a business relation.

\section{The Indonesian Society's Welfare}

According to Suryono (2014: 98) society's welfare is one of country's purposes. Kwok (2003: 2) said that Social welfare generally refers to states' services designed to protect citizens from the economic risks and insecurities of life. Welfare level refers to a community or society at large. Level of well-being includes food, education, and health. It sometimes also associated with job opportunities, the protection of the old days, free of poverty and so on. Welfare is a representation which is complex because it is a multidimensional, has linkages between dimensions and there is a dimension that is represented. 
Noll (n.y.: 4) mentioned the United Nations explanation that social indicators can be defined as statistics that usefully reflect important social conditions and that facilitate the process of assessing those conditions and their evolution. Social Indicators are used to identify social problems that require action, to develop priorities and goals for action and spending, and to assess the effectiveness of programmes and policies.

The formulation about the limitations between the substance of the well-being and welfare of representation determined by the development of privacy practices influenced by ideology and the performance of countries that did not escape the influence of dynamics on a global level. Puspitawati (2015: 2) mentioned some terms which are used to analyze the level of family welfare as follows:

a. Economical well-being: it is the economical welfare; the indicator which is used is income (GNP, GDP, income per capita per month, asset value).

b. Social well-being: it is social welfare; the indicator which is used is education level (elementary school/ junior high school/ senior high school/university; non formal education; educated or non educated) and status and kind of job (white collar = elit/ profesional, blue collar = proletar/ labour; having job or jobless).

c. Physical well-being: it is physical welfare; the indicator which is used is nutrient status, health status, mortality and morbiditas level.

d. Psychological/spiritual mental: it is psychological welfare; the indicator which is used is mental illness, stress level, suicidal level, divorce level, abortion level, criminal level (ravishment, looting/robbery, torturing/ embelishment, drugs, mutilation), free sex level.

Anderson (2000: 5) mentioned that in such a context, conventional social indicators may also constitute a sufficient basis for monitoring welfare trends: discrete 
indicators such as poverty head counts, years or level of school attainment, mortality and longevity, and unemployment rates. According to Purwana, welfare is the purpose of Islamic teaching in economic field. Welfare is a part of rahmatan lil alamin which is taught by Islam. However, the welfare which is mentioned in the holy Qur'an is not without requirements to gain it. Welfare will be given by Allah when the human being do what He order and leave what He forbids.

There are some verses in the holy Qur'an which discuss welfare, they are:

a. Al-Baqarah: 126

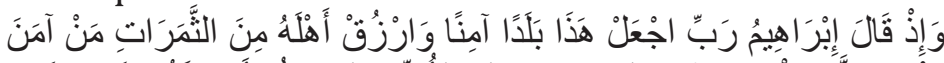

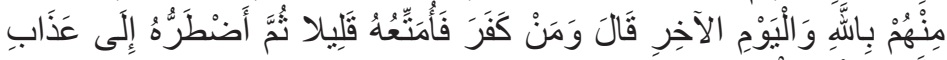

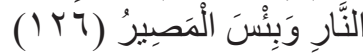

"And remember Abraham said:"My Lord, make this a City of Peace, and feed its Pole with fruits -such of them as belive in Allah and the last day. He said: "(Yea), and such as reject faith - for a while will I grant them their pleasure. But will soon drive them to the torment of fire an evil destination (indeed)!"

b. Al-Nisa: 9

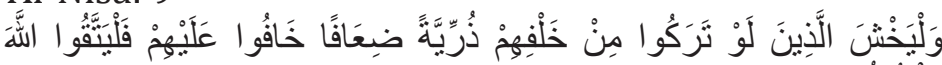

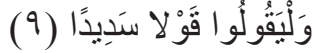

"Let those (disposing of an estate) have the same fear in their minds as they would have for their own if they had left a helpless family behind. Let them fear Allah, and speak words of appropriate (comfort)."

c. Al-A'raf: 10

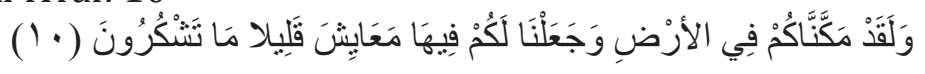

"It is we who have placed you with authority on earth, and provided you therein with means for the fulfillment of your life. Smaal are the thanks that we give." 
d. Al-Nahl: 97

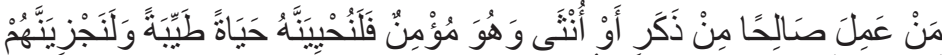

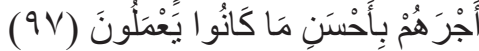

"Whoever works righteousness, man or woman, and has faith, verily, to him we will give a new life, and life that is good and pure, and we will bestow on such their reward according to the best of their actions."

e. Thaha: 117-119

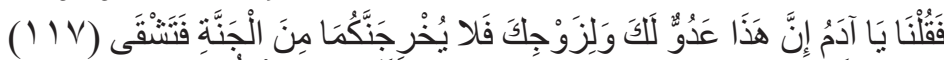

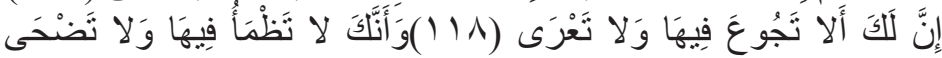

"Then we said: "O Adam! Verily, this is an enemy to thee and thy wife: so let him not get you both out of the garden, so that thou art landed in misery. There is therein (enough provision) for thee not to go hungry not to go naked. Nor to suffer from thirst, nor from the sun's heat."

Based on those verses, it can be known that welfare is only obtained with surrender fully to God the Almighty. Islamic teaching also teaches about the concepts of sharing. Sharing of the happiness and peace is not only for the individual but for the whole of mankind throughout the world. Welfare can be obtained only with a devotion to God the Almighty and also speak honestly and properly. In the verse 9 surah Al-Nisa, Allah asked his servant to pay attention to the well-being of future generations. Therefore, must be prepared a strong generation with pious to God the Almighty. Even Prophet Muhammad also banned to give the rest of his wealth to others by leaving his heir. The Prophet said: "If you leave your heirs in the enough state is better than leaving them in a state of poor and ask to others."

In the verse 9 of surah Al-A'raf, Allah the Almighty reminiscent of His servants to thanks for the favour that has been given by Him. The grace is a means to get welfare 
in the form of Earth which created by Him as a place to live, a place to meet all his life, gained control of the land, the result of its vegetation, animals, and mines.

Welfare is a guarantee or promise of Allah the Almighty which is given to men or women who are faithful to him. God the Almighty will also reply to various charitable good deeds people who tolerate with the better reward than their charity. The good life is the life of a happy, relaxed, and satisfied with the halal sustenance, including covering the whole shape of the peace of any kind and regardless of its shape.

Well-being according to the Qur'an reflected in Paradise inhabited by Prophets Adam and his wife shortly before they served as Caliph in the Earth. Well being described in the verse ensures the presence of food, clothing, and the board. It termed not hungry, don't feel thirst, not naked, and not overheating by the sun. While the opposite of it is a narrow life, which is far from a peaceful and quiet, always dissatisfied, chest tightness and edgy despite the inception seems luxurious, all-inclusive, enough clothing and place of residence.

According to al-Ghazali's well-being is the achievement of the benefits (maslahat). The maslahat is the maintenance of syara' goal (Maqasid al Shari'ah). Human beings cannot feel happiness and inner peace but rather after the accomplishment of the actual welfare of all mankind in the world through spiritually and material needs fulfillment. To achieve the goal of sharee'ah in order to be realized the maslahat, he outlines about the sources of well-being, including: the maintenance of religion, soul, intellect, lineage and property.

The treasure is an important means of creating the people well-being. In terms of specific thing, property can also create catastrophe and calamity for mankind. AlGhazali put the order of precedence in the fifth order in 
the maqasid al-shari'ah. Faith and possessions are very necessary in human happiness. However, it is faith that helps injecting a discipline and the meaning, so that it can carry possessions in accordance with Sharia.

\section{The Role of English Education in Increasing the Indonesian Society's Welfare}

Ndakularak, Setiawina, and Djayastra (n.y.: 150) mentioned that a prosperous man is an educated man. This means that the higher of education level a person has will give an impact on increasing revenues. An educated person will be easier to obtain a better job compared to the uneducated. To achieve a higher education really depends from the amount of money allocated for educational programs. The greater spending for education will increasingly give greater opportunities to achieve a higher level of education. As well as otherwise, the smaller spending for education programs will have an impact on the poor quality of education because one cannot reach the education with the quite expensive cost. This shows that household spending for education and the welfare of society are related positively. The larger the household spending for education, so the welfare society will be increased. In contrast, the smaller household spending for education will have an impact on the well-being of a society that is increasingly on the decline.

English as one of the compulsory subject which has been taught in every level of education in Indonesia has an important role in increasing the society's welfare. One of them is as a potential provision in entrepreneurship. In entrepreneurship need good communication skill, especially if the business wants to be developed in a larger scale. English skills can be an enough potential provision in entrepreneurship to keep it could develop a venture that built and can compete in the global era. In addition, 
the ability to speak in United Kingdom can also serve as an investment that can be made as provision in the running of the business.

Besides, it can be a major capital in the face of the era of the Asian Economic Society. Entering the globalization era or better known as the free market requires every individual to prepare reliable resources especially in the field of communication. In this case the role of English is indispensable both in mastering the technology of communication and interacting directly. As a global means of communication, English should be actively controlled whether oral or writing. Therefore, the need for paradigm change thinking about the importance of English, it is the new perception that in the era of globalization facing the Asian Economic Society, where the competitiveness of individuals from various countries compete each other in dominating a wide range of employment/business, in addition to the language of Indonesia as a unifying language (national language) that must be mastered, international language has become a second language should be compulsory and be possessed. As the world's lingua franca English not just as academic needs because the control was limited to the aspects of the knowledge of the language but rather as a global communication medium.

Additionally, it also supports to proceed to higher education level. To continue majoring or S3 are generally required having TOEFL score of about 480-500. Moreover, it also can be a provision in the following competition in the world of work. The current English language proficiency often served as one of the conditions for applying for a job. It can even be said nearly all professional work requires mastery of English. As mentioned by Rini (2014: 23) that English is regarded important because by mastering English, people can have higher salary and have better opportunities. English is also used in advertisements to give 
the impression that the products can give a higher prestige. Moreover, when applying in the international companies. Even if not required being able to speak English, a person who masters English would normally be preferred for a job. In addition, the English speaking cleverness can also increase confidence. So there is no feeling of minder when competing in the world of work.

English also can be a career support in the works. English has a significant role in the world of careers. English has been seen as the primary skills in a variety of professions in order to encourage improvement of the qualifications themselves. Therefore, the mastery of English for Indonesian people is no longer become a necessity or demands, but rather as a necessity and inevitability. English cannot be separated with a prospective employee to design career, and pursue a career or profession to reach a success. The English language which is a means of communication in the era of globalization becomes key success a person in achieving their career brighter.

The above explanation in line with Lauder (2008: 12) who mentioned that English plays an important role in some areas they are: economics and business, international relations, media (the world of current information and popular culture), education, communications, and international travel and safety.

\section{Conclusion}

Social welfare, especially in Indonesia always becomes an interesting topic to be discussed. It can be separated with the education. One of subject that has been taught in every level of education in Indonesia is Eglish. It has an important role in increasing the social welfare in Indonesia. By having a good mastery in English, people will have more opportunity to get a better job than others. In consequence, it will improve their income and get an improvement in their social welfare. 


\section{REFERENCES}

Ali, Abdullah Yusuf. 2002. The Meaning of the Holy Qur'an. Beltsville: Amana Publicationss.

Andersen, Gosta Esping. 2000. Social Indicators and Wefare Monitoring. Geneva: United Nations Research Institute for Social Development.

Idi, Abdullah. 2013. Sosiologi Pendidikan Individu, Masyarakat, dan Pendidikan. Jakarta: RajaGrafindo Persada.

Kwok, Joseph. 2003. Social welfare, social capital and social work: personal reflection of a Hong Kong Social Worker. Journal of Social Policy and Social Work No. 7, December. Japan: Japan College of Social Work.

Lauder, Allan. 2008. The Status and Function of English in Indonesia: A Review of Key Factors. Makara, Sosial Humaniora, Vol. 12, No. 1, Juli: 9-20. Jakarta: Departmen of Linguistics FIB University of Indonesia.

Ndkularak, E., Setiawina, N.D., and Djayastra, I.K. n.y. Analisis Faktorfaktor yang Mempengaruhi Kesejahteraan Masyarakat Kabupaten Kota di Provinsi Bali. Bali: Universitas Udayana.

Noll, Heinz-Herbert. N.y. Social Indicators and Quality of Life Research: Background, Achievements and Current Trends. Mannheim: ZUMA - Centre for Survey Research and Methodology.

Purwana, Agung Eko. n.y. Kesejahteraan dalam Perspektif Ekonomi Islam. Ponorogo: Jurusan Syariah dan Ekonomi Islam STAIN Ponorogo.

Puspitawati, Herien. 2015. Kajian Akademik Pengertian Kesejahteraan dan Ketahanan Keluarga. Bogor: Departemen Ilmu Keluarga dan Konsumen Fakultas Ekologi Manusia, Institut Pertanian Bogor.

Rini, Julia Eka. 2014. English in Indonesia: Its Position Among Other 
Language in Indonesia.beyond Words Vol. 2, No. 2. Surabaya: Widya Mandala Catholic University.

Suryono, Agus. 2014. Kebijakan Publik untuk Kesejahteraan Rakyat. TRANSPARANSI - Jurnal Ilmiah Ilmu Administrasi. Malang: Universitas Brawijaya. 